\title{
Terapi Farmakologi Nyeri pada Amyotrophic Lateral Sclerosis
}

\author{
Indira D. Mahdayana ${ }^{1}$, Hanik B. Hidayati ${ }^{2}$ \\ ${ }^{1}$ Departemen Farmasi Klinik, Fakultas Farmasi, Universitas Airlangga, Surabaya, Indonesia, \\ ${ }^{2}$ Staf Medis Fungsional Ilmu Penyakit Saraf, RSUD Dr. Soetomo, Surabaya, Indonesia
}

\begin{abstract}
Abstrak
Amyotrophic lateral sclerosis (ALS) merupakan penyakit neurodegeneratif fatal yang memengaruhi motor neuron. Nyeri merupakan gangguan sensoris yang dapat timbul pada ALS dan gejala yang seringkali diremehkan dan diabaikan pada pasien dengan ALS. Sampai saat ini, terapi nyeri hanya didasarkan pada pengalaman klinisi dan belum terdapat tata laksana nyeri yang terstandarisasi untuk pasien ALS. Oleh karena itu, tinjauan pustaka ini bertujuan untuk membahas gambaran klinis dan tata laksana nyeri pada ALS. Penelusuran referensi dilakukan melalui database PubMed dan Google Scholar dengan menggunakan kata kunci "Amyotrophic Lateral Sclerosis", "pain", "pharmacology", dan "therapy". Hasil penelusuran menunjukkan bahwa terdapat beberapa gambaran klinis nyeri pada ALS, seperti kram, spastisitas dan nyeri muskuloskeletal, sehingga tata laksana nyeri pada ALS harus didasarkan pada penyebab utama timbulnya nyeri. Terbatasnya evidence terkait terapi nyeri pada ALS menyebabkan pemberian terapi tidak dilakukan berdasarkan pendekatan sistematis, sehingga dibutuhkan studi lebih lanjut terkait efikasi dari terapi nyeri ALS.
\end{abstract}

Kata kunci: Amyotrophic lateral sclerosis, farmakologi, nyeri, terapi

\section{Pharmacology Therapy for Pain in Amyotrophic Lateral Sclerosis}

\begin{abstract}
The cause of motor neurons is amyotrophic lateral sclerosis (ALS), a fatal neurodegenerative disease with the potential to cause a frequently ignored sensory disorder called pain. Furthermore, pain therapy today is usually based on the clinician's experience while standardized pain management for ALS patients is unused. Therefore, this literature review aimed to explore ALS clinical features and pain management. The database investigation was performed on PubMed and Google Scholar using the keywords "Amyotrophic Lateral Sclerosis", "pain", "pharmacology", and "therapy". The results showed the presence of several pain clinical features in ALS, including cramps, spasticity and musculoskeletal pain, and therefore the need for ALS pain supervision to be based on the major cause. However, there were limited evidence reported investigating the effectiveness of drug therapy for this pain, and further research is required to discover efficient and safe pain treatment agents.
\end{abstract}

Keywords: Amyotrophic lateral sclerosis, pain, pharmacology, therapy

Korespondensi: Dr. dr. Hanik B. Hidayati, Sp.S(K), SMF Ilmu Penyakit Saraf, RSUD Dr. Soetomo, Surabaya, Jawa Timur60286, Indonesia, email: hanikhidayati@yahoo.com

Naskah diterima: 29 Februari 2020, Diterima untuk diterbitkan: 11 November 2020, Diterbitkan: 9 Desember 2020 


\section{Pendahuluan}

Amyotrophic lateral sclerosis (ALS) adalah sebuah penyakit neurodegeneratif fatal yang memengaruhi saraf motor dan sel-sel neuronal lain, ditandai oleh gejala degenerasi dari upper motor neuron (UMN) dengan manifestasi klinis spastisitas dan refleks berlebihan di korteks motor serta lower motor neuron (LMN) dengan manifestasi klinis atrofi, kelemahan dan fasikulasi otot di sumsum tulang dan batang otak. Berbagai manifestasi ini akan menyebabkan paresis yang berpengaruh terhadap mobilitas, aktivitas sehari-hari, fungsi komunikasi, menelan, dan pernafasan pasien. ${ }^{1,2}$

Nyeri merupakan komplikasi gangguan sensoris pada ALS, dan merupakan gejala yang seringkali diremehkan dan diabaikan pada ALS. Diketahui dibutuhkan waktu sekitar 30 tahun sampai tenaga kesehatan dapat aware dengan nyeri pada ALS. Pada beberapa studi cross-sectional, dilaporkan sebesar 51-72\% pasien ALS mengalami nyeri. Sebanyak 25\% pasien ALS pada sebuah case-control study mengalami nyeri sebelum diagnosis ALS ditegakkan dengan tingkat moderate hingga severe. ${ }^{3,4}$ Terdapat beberapa jenis gambaran klinis yang mendasari timbulnya nyeri pada ALS, di antaranya adalah muskuloskeletal, spastisitas, kram otot dan fasikulasi..$^{5-7} \mathrm{Kram}$ disertai nyeri pada kaki dan tangan seringkali muncul pada onset awal munculnya ALS. ${ }^{8,9}$

Terapi farmakologi sampai saat ini hanya didasarkan pada pengalaman klinisi, sehingga tata laksana terapi, metode diagnosis dan mekanisme yang mendasari timbulnya nyeri pada ALS belum sepenuhnya terstandarisasi. ${ }^{6,7}$ Oleh karena itu, tinjauan pustaka ini bertujuan membahas terkait gambaran klinis dan tata laksana nyeri pada ALS secara komprehensif.

\section{Metode}

Metode yang digunakan dalam tinjauan pustaka ini adalah penelusuran literatur yang berkaitan dengan gambaran klinis dan tatalaksana nyeri pada ALS. Penelusuran yang dilakukan berbasis Pubmed dan Google Scholar dengan kata kunci "Amyotrophic Lateral Sclerosis", "pain", "pharmacology", dan "therapy". Kriteria inklusi pada tinjauan pustaka ini yaitu: (1) Penelitian menjelaskan tentang gambaran klinis dan tata laksana nyeri pada ALS; (2) Artikel berbahasa Inggris yang diterbitkan mulai tahun 2015 hingga 2020; dan (3) Artikel yang tersedia teks lengkapnya (baik dalam bentuk abstrak atau prosiding). Dari hasil penelusuran, diperoleh sebanyak 197 artikel di database PubMed dan sebanyak 6050 artikel di database Google Scholar. Selanjutnya, dilakukan pengerucutan dengan menyaring artikel yang sesuai dengan kriteria inklusi. Oleh karena itu, jurnal yang digunakan dalam penusunan tinjauan pustaka ini adalah sebanyak 45 artikel (Gambar 1).

\section{Hasil}

\section{Etiopatogenesis nyeri pada ALS}

Nyeri dapat dideskripsikan sebagai rasa tidak menyenangkan dan perasaan emosional sebagai respon terhadap stimulus noxious, kerusakan jaringan atau trauma. ${ }^{10}$ Manifestasi nyeri dapat muncul berbeda-beda pada pasien bergantung pada usia, progresivitas, gambaran klinis dan penyebab primer dan sekunder penyakit. ${ }^{9,11}$ Hal ini menyebabkan terjadinya variabilitas prevalensi kemunculan nyeri pada ALS sekitar 15-85\%. ${ }^{12}$ Persepsi severitas nyeri pada pasien ALS juga akan bervariasi antarindividu tergantung tingkat toleransi pasien terhadap nyeri. ${ }^{13}$

Nyeri dapat diklasifikasikan menjadi nyeri akut atau kronik bergantung pada durasi serta adanya abnormalitas struktural dan/atau fungsional yang memengaruhi kerja saraf dalam mengirimkan informasi nosiseptif ke sistem saraf pusat. ${ }^{10}$ Beberapa studi klinis melaporkan bahwa tidak terdapat hubungan signifikan antara onset terjadinya manifestasi 


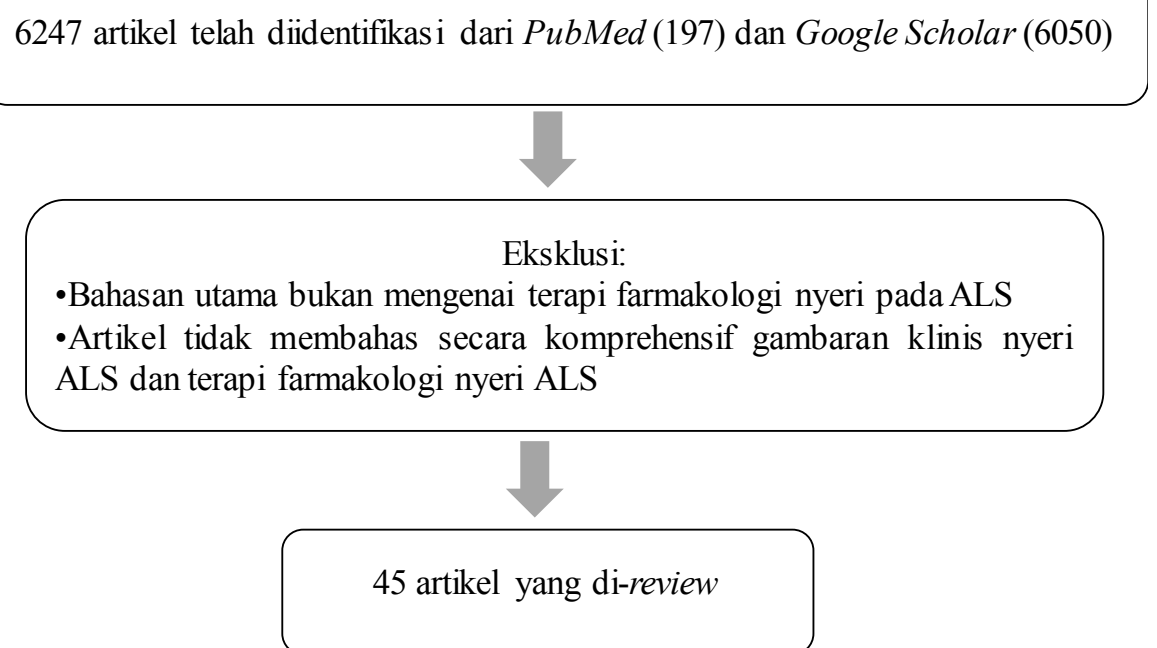

Gambar 1 Proses Seleksi Artikel

awal ALS atau progresivitas ALS terhadap skala nyeri pasien. ${ }^{9,11,14}$

Etiologi nyeri pada ALS dapat terjadi dengan mekanisme yang berbeda, yaitu kram otot, spastisitas maupun tekanan yang abnormal pada sistem muskuloskeletal otototot yang mengalami kelemahan serta nyeri sendi akibat imobilisasi atau blokade pada artikular. Kelemahan otot dapat menyebabkan ketegangan yang berlebih pada otot dan sendi. ${ }^{3}$

Nyeri pada ALS dilaporkan sering terjadi pada bagian ekstrimitas yaitu leher, bahu dan punggung bagian bawah. Imobilitas atau ketidakmampuan pasien untuk berganti posisi dalam waktu yang lama dapat menyebabkan tekanan abnormal pada kulit, sehingga juga dapat memicu timbulnya nyeri bahkan luka pada kulit (pressure ulcer). ${ }^{9,15}$ Nyeri punggung bagian bawah pada ALS dapat dipicu akibat posisi duduk atau posisi pasien yang tidak nyaman. Nyeri leher berhubungan dengan drop head yang merupakan masalah nyeri muskuloskeletal yang paling sulit untuk diatasi. Sampai saat ini, belum diketahui apakah terdapat lokalisasi nyeri yang khas pada ALS, karena nyeri dapat terjadi lebih dari satu lokasi dan tiap lokasi tidak memiliki pola karakteristik tertentu. ${ }^{7,13,14}$ Usia dan jenis kelamin tidak mempunyai pengaruh terkait karakteristik nyeri pada ALS. ${ }^{11}$

\section{Gambaran klinis nyeri pada ALS}

Kram otot

Kram otot dapat terjadi akibat hipereksitabilitas neuromuskular dan dapat diikuti dengan nyeri punggung bawah. ${ }^{16}$ Penyebab kram otot pada ALS adalah gangguan mekanisme inhibitory pada interneuron yang dimediasi oleh gamma aminobutyric acid (GABA)., 717

Kram merupakan penyebab utama nyeri pada sekitar seperempat pasien ALS dan biasanya muncul pada stage awal dan intermediate dari penyakit ALS. ${ }^{18}$ Kejadian kram utamanya terjadi pada malam hari dan diperburuk dengan cuaca yang dingin atau akibat penurunan sirkulasi akibat pasien terlalu lama berada pada satu posisi. ${ }^{19}$ Seiring berjalannya waktu, manifestasi kejadian kram akan menurun. Hal ini karena pada stadium lanjut, sel-sel saraf akan kehilangan kemampuan untuk menstimulasi kontraksi otot. $^{20}$

\section{Spastisitas}

Spastisitas merupakan manifestasi klinis berupa peningkatan tonus otot yang juga 


\section{Tabel 1 Terapi Farmakologi Nyeri pada ALS}

\begin{tabular}{|c|c|c|c|c|c|}
\hline Obat & Mekanisme Kerja & Dosis & Adjustment Dosis & Efek Samping & Kontraindikasi \\
\hline \multicolumn{6}{|c|}{ Kram (Ekstrimitas bagian bawah, tangan, perut) } \\
\hline Siklobenzaprin & $\begin{array}{l}\text { 1. Merupakan CNS depressant } \\
\text { yang berkerja utamanya pada } \\
\text { brain stem level } \\
\text { 2. Mengurangi eksitabilitas } \\
\text { dari alpha dan gamma motor } \\
\text { neuron }^{24}\end{array}$ & $\begin{array}{l}\text { Initial: } 5 \mathrm{mg} / 8 \text { jam PO } \\
\text { Dosis dapat ditingkatkan } \\
\text { hingga } 7,5 \mathrm{mg} \text { atau } 10 \\
\mathrm{mg} / 8 \mathrm{jam} \text { selama } 2-3 \\
\text { minggu }^{24,25} \\
\text { Dosis untuk lansia } \\
\text { direkomendasikan } 5 \mathrm{mg} / \\
\text { hari dan less frequent } \\
\text { dosing }\end{array}$ & $\begin{array}{l}\text { Hepar: } \\
\text { Mild: initial dose } 5 \mathrm{mg} \text { dan } \\
\text { titrasi dengan monitoring } \\
\text { Moderate-severe: Penggunaan } \\
\text { tidak direkomendasikan } \\
\text { Renal: Tidak ada }{ }^{24,25}\end{array}$ & $\begin{array}{l}\text { Efek antikolinergik } \\
\text { (pusing, konstipasi, ocular } \\
\text { hypertension, retensi urin), } \\
\text { sinus takikardi, palpitasi, } \\
\text { gangguan konduksi }{ }^{25}\end{array}$ & $\begin{array}{l}\text { Terapi tidak } \\
\text { direkomendasikan }>3 \text { minggu, } \\
\text { hindari pemberian pada } \\
\text { lansia, pasien dengan aritmia, } \\
\text { closed angle glaucoma }^{25}\end{array}$ \\
\hline Metaksalon & $\begin{array}{l}\text { Melalui efek myorelaxation } \\
\text { akibat efek sedasi }{ }^{26}\end{array}$ & $800 \mathrm{mg} / 12 \mathrm{jam} \mathrm{PO}^{27}$ & $\begin{array}{l}\text { Hepar: Tidak ada } \\
\text { Renal: Tidak ada }{ }^{26}\end{array}$ & $\begin{array}{l}\text { Pusing }(<5 \%) \text {, iritabilitas, } \\
\text { gangguan saluran cerna. } \\
\text { Penggunaan bersama } \\
\text { dengan opioid, } \\
\text { benzodiazepine atau } \\
\text { barbiturat dapat } \\
\text { menyebabkan depresi } \\
\text { nafas }^{26}\end{array}$ & $\begin{array}{l}\text { Gangguan hepar atau renal } \\
\text { severe }^{26}\end{array}$ \\
\hline Quinin sulfat & $\begin{array}{l}\text { Mengurangi eksitabiltias motor } \\
\text { end-plate dan meningkatkan } \\
\text { periode refraktori otot } 28\end{array}$ & $200-300 \mathrm{mg} / 12 \mathrm{jam}^{29,30}$ & $\begin{array}{l}\text { Hepar: } \\
\text { Mild-moderate (Child Pugh } \\
\text { A-B): Tidak dibutuhkan } \\
\text { penyesuaian dosis } 30 \\
\text { Severe (Child Pugh } \\
\text { C): Penggunaan tidak } \\
\text { direkomendasikan } \\
\text { Renal: Tidak ada }\end{array}$ & $\begin{array}{l}\text { Abnormalitas konduksi } \\
\text { ventrikular, gangguan } \\
\text { fungsi renal severe }\end{array}$ & $\begin{array}{l}\text { Gangguan fungsi renal atau } \\
\text { hepar, hipokalemi, bradikardi, } \\
\text { aritmia, pemajangan Q-T } \\
\text { interval }^{24}\end{array}$ \\
\hline Levetirasetam & $\begin{array}{l}\text { 1. GABA } \text { agonis reseptor } \\
\text { 2. Menghambat neurotransmisi } \\
\text { melalui modulasi tidak } \\
\text { langsung dari GABA } \text { dan } \\
\text { reseptor glisin, serta menekan } \\
\text { kanal Ca yang mana akan } \\
\text { menyebabkan hambatan } \\
\text { presinaptik pada spinal cord }{ }^{31}\end{array}$ & $1500 \mathrm{mg} /$ hari $\mathrm{PO}^{31,32}$ & $\begin{array}{l}\text { Hepar: Tidak ada } \\
\text { Renal: } \\
\text { ClCr } 50-80 \mathrm{ml} / \text { menit: } 500-1000 \\
\mathrm{mg} / 12 \text { jam } \\
\mathrm{ClCr} 30-50 \mathrm{ml} / \mathrm{menit}: 250-750 \\
\mathrm{mg} / 12 \mathrm{jam} \\
\mathrm{ClCr}<30 \mathrm{ml} / \text { menit: } 250-500 \\
\mathrm{mg} / 12 \mathrm{jam} 27\end{array}$ & $\begin{array}{l}\text { Lelah, mengantuk, } \\
\text { insomnia, sakit kepala }{ }^{33}\end{array}$ & $\begin{array}{l}\text { Aritmia jantung, } \\
\text { atrioventricular block, depresi } \text { severe }^{33}\end{array}$ \\
\hline
\end{tabular}


Tabel 1 Terapi Farmakologi Nyeri pada ALS (Lanjutan)

\begin{tabular}{|c|c|c|c|c|c|}
\hline Obat & Mekanisme Kerja & Dosis & Adjustment Dosis & Efek Samping & Kontraindikasi \\
\hline Gabapentin & $\begin{array}{l}\text { Menghambat } \alpha_{2} \delta \text { subunit dari } \\
\text { L-type kanal } \mathrm{Ca}^{2+} \text { yang akan } \\
\text { menghambat rilis glutamat }{ }^{34,35}\end{array}$ & $\begin{array}{l}\text { 1200-3600 mg/hari } \\
\text { (diberikan 3-4 kali } \\
\text { per hari dalam dosis } \\
\text { terbagi }{ }^{34,35}\end{array}$ & $\begin{array}{l}\text { Hepar: Tidak ada } \\
\text { Renal: } \\
\text { ClCr }>30-59 \mathrm{ml} / \text { menit: } \\
\text { 200-700mg/12 jam } \\
\mathrm{ClCr}>15-29 \mathrm{ml} / \text { menit: } 200-700 \\
\mathrm{mg} / \text { hari } \\
\mathrm{ClCr} \leq 15 \mathrm{ml} / \text { menit: } 100-300 \\
\mathrm{mg} / \text { hari }^{35,36}\end{array}$ & $\begin{array}{l}\text { Edema perifer, peningkatan } \\
\text { berat badan, penurunan } \\
\text { memori }^{35}\end{array}$ & Gangguan psikiatrik $^{50}$ \\
\hline Meksiletin & $\begin{array}{l}\text { Menghambat kanal } \mathrm{Na}+ \\
\text { sehingga mengurangi influks } \\
\mathrm{Na}+\text { pada distal akson }{ }^{16}\end{array}$ & $\begin{array}{l}150 \mathrm{mg} / 12 \mathrm{jam} \\
\text { Do maksimal: } 900 \mathrm{mg} / \\
\text { hari }^{37}\end{array}$ & $\begin{array}{l}\text { Hepar: } \\
\text { Renal: } \\
\mathrm{ClCr}<10 \mathrm{ml} / \text { menit: dapat } \\
\text { diberikan } 50-100 \% \text { dari dosis } \\
\text { normal dan dosis dapat dititrasi } \\
\text { sesuai respon pasien }^{37,38}\end{array}$ & $\begin{array}{l}\text { Gangguan saluran cerna, } \\
\text { sakit kepala ringan, lemas }{ }^{37}\end{array}$ & $\begin{array}{l}\text { Gangguan jantung, gangguan } \\
\text { hepar }^{37}\end{array}$ \\
\hline \multicolumn{6}{|c|}{ Spastisitas (Ekstrimitas bagian bawah) } \\
\hline Baklofen & $\begin{array}{l}\text { 1. } \mathrm{GABA}_{\mathrm{B}} \text { agonis reseptor } \\
\text { 2. Menghambat rilis glutamat } \\
\text { presinaptik dan postsinaptik }\end{array}$ & $\begin{array}{l}\text { Initial PO: } 5 \mathrm{mg} / 8 \text { jam } \\
\text { Do maksimal: } 80 \mathrm{mg} / \text { hari } \\
(20 \mathrm{mg} / 6 \text { jam) } \\
\text { Dosis dapat ditingkatkan } \\
\text { tiap } 3 \text { hari (berdasarkan } \\
\text { respon pasien) } \\
\text { Do IT: } 50 \mathrm{mcg} \\
\text { Do maksimal: } 2 \mathrm{mg} / \text { hari }^{39} \\
\text { Observasi tiap } 4-8 \text { jam }^{39}\end{array}$ & $\begin{array}{l}\text { Hepar: Tidak ada } \\
\text { Renal: Tidak diperlukan } \\
\text { penyesuaian dosis }\end{array}$ & $\begin{array}{l}\text { Pusing (biasanya muncul } \\
\text { pada awal pemberian } \\
\text { terapi), peningkatan } \\
\text { tekanan darah, mengantuk, } \\
\text { withdrawal syndrome (jika } \\
\text { dilakukan penghentian } \\
\text { terapi mendadak) }{ }^{18,40-42}\end{array}$ & $\begin{array}{l}\text { Hepatotoksik } \rightarrow \text { Lakukan } \\
\text { monitoring fungsi hepar } \\
\text { rutin }^{39}\end{array}$ \\
\hline Tizanidin & $\begin{array}{l}\text { 1. Mempunyai struktur yang } \\
\text { sama dengan Clonidin } \\
\text { 2. Centrally acting alpha }{ }_{2} \\
\text { agonist } \\
\text { 3. Menghambat motor neuron } \\
\text { alpha, presinaptik dan } \\
\text { postsinaptik } \\
\text { 4. Dapat memotensiasi kerja } \\
\text { dari glisin }{ }^{43,44}\end{array}$ & $\begin{array}{l}\text { Initial: } 2-4 \mathrm{mg} / 12 \mathrm{jam} \\
\mathrm{PO}^{24,43} \\
\text { Dosis maksimal: } 36 \mathrm{mg} / \\
\text { hari (dapat diberikan } \\
\text { dalam dosis terbagi } \rightarrow 12 \\
\mathrm{mg} / 8 \mathrm{jam})\end{array}$ & $\begin{array}{l}\text { Hepar: Hindari penggunaan } \\
\text { pada pasien dengan gangguan } \\
\text { hepar } \rightarrow \text { namun dapat diberikan } \\
\text { dengan mengurangi initial dose } \\
\text { Renal: } \mathrm{ClCr}<25 \mathrm{ml} / \text { menit } \rightarrow^{\rightarrow} \\
\text { berikan dengan pengawasan }\end{array}$ & 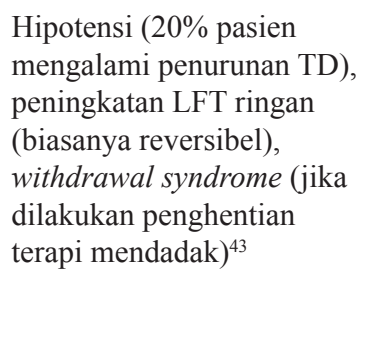 & $\begin{array}{l}\text { Gangguan ginjal, gangguan } \\
\text { hepar }^{56}\end{array}$ \\
\hline
\end{tabular}




\section{Tabel 1 Terapi Farmakologi Nyeri pada ALS (Lanjutan)}

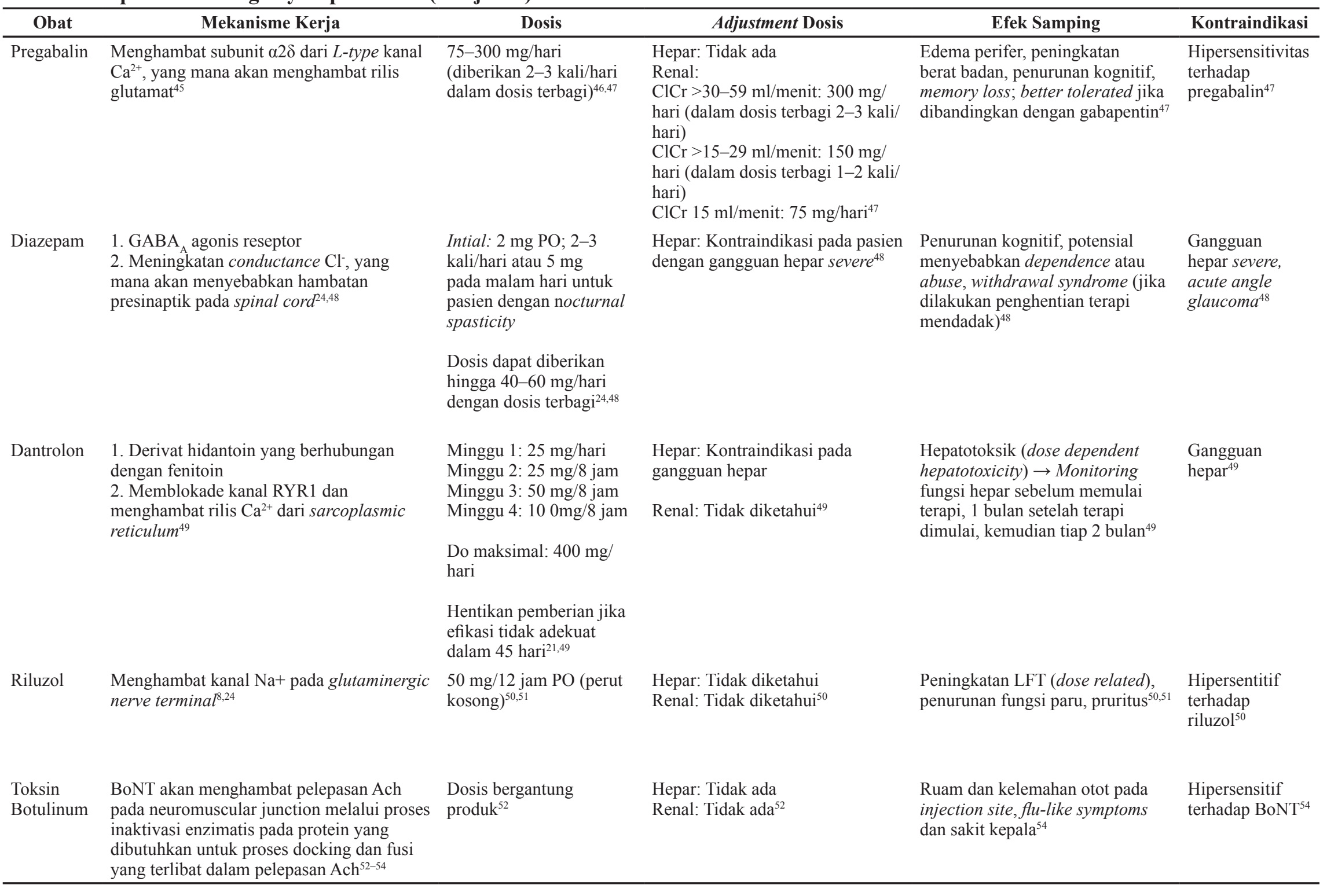


seringkali menyertai pasien ALS. Terdapat dua jenis manifestasi klinis spastisitas yaitu, spastisitas tonik yang dapat menyebabkan terjadinya kekakuan otot dan spastisitas fasik yang menghasilkan kram disertai nyeri, kejang otot, dan klonus. ${ }^{19}$

Spasme otot pada ALS terjadi akibat tidak terkontrolnya refleks peregangan di korteks motorik dan berhubungan dengan proprioceptive input yang abnormal pada myelum. Ketidakseimbangan penghambatan supraspinal dan input eksikatori juga dapat mengganggu refleks nosiseptif, sehingga mengarah pada spasme pergerakan fleksi dan ekstensi. Spastisitas dapat menjalar pada anggota gerak yang mengalami kelemahan dan atrofi. Pada stadium lanjut, pasien dapat mengalami flexor spasms. Flexor spasms dapat menyebabkan spasme tidak terkontrol akibat aktivasi flexor arc di spastic limb. Frekuensi munculnya spastisitas dapat terjadi secara intermiten maupun kontinu. ${ }^{20}$

Nyeri muskuloskeletal dan nyeri sendi Pada ALS stadium lanjut, seiring dengan progresivitas penyakit dan penurunan mobilitas pasien, nyeri muskuloskeletal akan muncul. Nyeri dapat diakibatkan oleh perubahan tone di sekitar sendi, kekakuan dan atrofi, hilangnya muscular sheath dan menurunnya tonus otot. Nyeri muskuloskeletal yang dapat ditemui pada pasien ALS meliputi adhesive capsulitis (frozen shoulder), nyeri punggung bawah dan leher akibat kelemahan otot dan imobilitas dalam waktu yang lama. ${ }^{11,21}$

\section{Terapi farmakologi nyeri pada ALS}

Nyeri berkaitan erat dengan kualitas hidup pasien ALS, sehingga klinisi harus dapat mengidentifikasi dan mengatasi nyeri dengan sesegera mungkin atau mencegah agar nyeri tidak muncul kembali., Jenis nyeri pada pasien ALS dapat bervariasi, sehingga terapi harus disesuaikan dengan penyebab timbulnya nyeri. ${ }^{8}$
Tata laksana nyeri pada ALS terdiri dari non-farmakologi dan farmakologi. Terapi non-farmakologi terdiri dari fisioterapi, peregangan teratur dan latihan Range of Motion (ROM) yang dapat dikombinasikan dengan terapi farmakologi. ${ }^{22,23}$ Rekomendasi terkait tata laksana terapi farmakologi nyeri terangkum pada Tabel 1.

Terapi farmakologi kram otot

Terapi kram otot bertujuan untuk mengurangi ketegangan otot. Terdapat sedikit perbedaan di beberapa negara terkait tata laksana kram otot pada pasien dengan ALS. Prancis dan Amerika lebih banyak menggunakan quinin sebagai lini pertama terapi kram otot pada pasien ALS, sedangkan European Federation of Neurological Societies (EFNS) merekomendasikan levetirasetam sebagai lini pertama dan quinin sebagai lini ke dua. ${ }^{9,19}$ Penggunaan rutin quinin sebagai terapi kram otot harus dihindari, meskipun quinin diketahui efektif (level A) sebagai terapi untuk kram otot. Hal ini terkait efek samping quinin yang cukup banyak dilaporkan, ${ }^{28}$ yaitu efek samping hematologi (meliputi immune thrombocytopenic purpura dan drug mediated thrombotic microangiopathy) yang jarang terjadi namun cukup serius. ${ }^{18,29,55}$ Hal ini didukung oleh Food and Drug Administration (FDA) yang tidak merekomendasikan quinin sebagai terapi atau pencegahan kram otot.,46 Jika levetirasetam dan quinin tidak adekuat, maka dapat diberikan siklobenzaprin dan metaksalon. ${ }^{3}$

Telah dilakukan beberapa studi randomized controlled trial (RCT) yang dilakukan untuk melihat efektivitas beberapa obat dalam meredakan kram pada pasien ALS. Obatobat tersebut adalah gabapentin, vitamin $\mathrm{E},{ }^{19}$ L-threonin, memantin, ${ }^{56}$ xaliproden, indinavir, baklofen dan mexiletin. ${ }^{16}$ Dari semua studi tersebut, meksiletin dengan dosis $150 \mathrm{mg} / 12$ jam PO merupakan satu-satunya terapi yang mempunyai efek signifikan dalam 
mengurangi frekuensi dan severitas dari kram otot pada pasien ALS dengan desain penelitian RCT. ${ }^{16,18,57}$

\section{Terapi farmakologi spastisitas}

Terapi anti spastisitas dilakukan dengan tujuan menurunkan tonus otot dengan mekanisme pada central nervous system (CNS) atau secara langsung pada otot skeletal. ${ }^{27,51,58}$ National Institute for Health and Care Excellence (NICE) merekomendasikan baklofen sebagai terapi lini pertama, sedangkan lini kedua adalah tizanidin, dantrolon dan gabapentin. Secara umum, obat anti spastisitas dapat menyebabkan kelelahan dan mual, sehingga terkait peningkatan dosis harus dilakukan dengan sangat hati-hati untuk membantu meningkatkan kepatuhan pasien. ${ }^{19,51,59}$

Terapi oral kombinasi dan pemberian baklofen rute intratekal (IT) dapat dilakukan jika spastisitas berat tidak teratasi dengan terapi oral tunggal maupun physical therapy. ${ }^{18,20,42}$ Namun, hingga saat ini belum banyak evidence yang membahas penggunaan kombinasi oral anti spastisitas. Kombinasi dua obat hanya dapat digunakan pada kondisi khusus, yaitu saat terapi tunggal tidak adekuat dan pasien hanya dapat mentoleransi obat anti spastisitas dengan dosis kecil. Pemberian terapi harus dimulai dari dosis terkecil dan ditingkatkan sedikit demi sedikit. Evaluasi efektivitas terapi harus dilakukan secara periodik dan bila dirasa tidak adekuat maka terapi dapat dihentikan dengan tappering dosis terlebih dahulu, untuk mencegah rebound spastisitas akibat penghentian terapi secara tiba-tiba. ${ }^{59}$

Pada pemberian baklofen IT jangka panjang, sekitar 5\% pasien akan mengalami toleransi terhadap peningkatan dosis. Hal ini dapat menyebabkan penurunan efikasi terapi, sehingga untuk mengembalikan sensitivitas pasien terhadap baklofen, dilakukan "drug holiday". Pada drug holiday, dosis baklofen IT diturunkan secara bertahap dalam 2-4 minggu dan kemudian dilakukan penggantian dengan terapi anti spastisitas lainnya. Alternatif yang dapat digunakan adalah morfin sulfat IT free preservative. Setelah periode drug holiday ini, terapi baklofen IT dapat dilanjutkan kembali dengan dosis initial yang kemudian dapat ditingkatkan secara bertahap. ${ }^{40}$

American Academy of Neurology (AAN) juga telah mengeluarkan guideline terapi anti spastisitas dengan menggunakan botulinum neurotoxin (BoNT). Terdapat 4 jenis sediaan BoNT yang saat ini beredar di pasaran, antara lain onabotulinumtoxinA (onaBoNT-A), abobotulinumtoxinA (aboBoNT-A), incobotulinumtoxinA (incoBoNT-A) dan rimabotulinumtoxinB (rimaBoNT-B) dengan rute pemberian injeksi lokal. ${ }^{52,60}$ AAN merekomendasikan penggunaan aboBoNT-A, incoBoNT-A, dan onaBoNT-A yang telah terbukti efektif untuk penanganan spastisitas pada ekstrimitas atas (level rekomendasi A) dan rimaBoNT-B mungkin dapat efektif dan dapat dipertimbangkan untuk spastisitas pada ekstrimitas atas (level rekomendasi B). AboBoNT-A dan onaBoNT-A juga efektif dan dapat direkomendasikan untuk spastisitas pada ekstrimitas bawah (level rekomendasi A). ${ }^{52}$ Mula kerja BoNT untuk spastisitas akan muncul rata-rata pada 14 hari dan akan bertahan hingga 3 bulan. Efek terapeutik akan berkurang saat neuron motorik mulai membentuk nerve terminal yang baru, sehingga Ach akan diproduksi kembali. ${ }^{61}$

Terapi farmakologi nyeri muskuloskeletal dan nyeri sendi

Terapi nyeri yang dapat diberikan untuk nyeri muskuloskeletal dan sendi pada ALS adalah asetaminofen atau nonsteroid antiinflammatory drugs (NSAID) untuk nyeri moderate sampai severe. ${ }^{21}$ Opioid biasanya diberikan jika lini pertama tidak adekuat, sehingga opioid hanya diberikan pada pasien dengan very late stage ALS. ${ }^{1,3}$ Diketahui sebesar 70\% pasien dengan advanced ALS mengalami perbaikan skala nyeri dengan 
pemberian opioid. ${ }^{20}$ Morfin merupakan jenis opioid yang paling banyak diberikan pada very late stage ALS. Morfin eliksir atau tablet dapat diberikan tiap 4 jam atau kapsul tiap 12 jam. Analgesik kuat lainnya yang dapat diberikan adalah oksikodon kapsul, tablet atau fentanil transdermal patch yang dapat digunakan jika pasien mengalami sulit menelan. Terkait regimentasi dan pola penggunaan analgesik pada ALS, AAN merekomendasikan agar merujuk pada World Health Organization (WHO) pain ladder. ${ }^{1,21}$

Penggunaan opioid jangka panjang dapat menyebabkan hipogonadisme atau bahkan peningkatan sensitivitas terhadap stimulus nyeri. Kondisi ini disebut opioid-induced hyperalgesia yang dapat terjadi ketika pasien mengalami paparan opioid secara berulang atau berkepanjangan sehingga menyebabkan pasien menjadi semakin sensitif terhadap nyeri atau menyebabkan intensitas, kualitas, dan frekuensi nyeri semakin meningkat. Jika hal ini terjadi, dosis opioid harus dikurangi secara bertahap dan dilakukan penggantian terapi ke golongan non-opioid. ${ }^{34}$ Withdrawal syndrome dapat terjadi 12 jam setelah opioid dihentikan tiba-tiba, sehingga tappering dosis harus dilakukan sebelum penghentian terapi. ${ }^{62}$

\section{Pembahasan}

Terapi kram pada ALS sebagian besar masih berdasarkan data empiris dan tidak didukung dengan data yang sistematik. Levetirasetam merupakan terapi yang telah direkomendasikan EFNS sebagai lini pertama (level A) untuk mengatasi kram pada ALS. Efektivitas levetirasetam pada kram pada pasien ALS telah dilaporkan dalam uji klinis, namun hasil ini terbatas pada non controlled and openlabel study. ${ }^{9,19,63}$ Quinin sulfat juga merupakan salah satu obat yang sering digunakan oleh Prancis untuk terapi kram pada ALS, namun FDA telah mengeluarkan himbauan terkait keamanan penggunaan quinin sulfat yang hanya terbatas pada terapi untuk malaria dan tidak untuk terapi atau pencegahan pada kram. Efikasi yang superior dari quinin sulfat dibandingkan dengan plasebo atau intervensi lainnya telah diulas dalam review Cochrane, namun tidak spesifik untuk kram pada ALS. Review tersebut menunjukkan bahwa quinin (200-500 $\mathrm{mg} /$ hari) dapat menurunkan frekuensi dan intensitas kram jika dibandingkan dengan plasebo. Evidence dari single trial hanya menunjukkan jika teofilin dikombinasikan dengan quinin dapat memperbaiki kram jika dibandingkan quinin tunggal. Low quality evidence menunjukkan tidak ada perbedaan signifikan antara quinin dan vitamin $\mathrm{E}$, quinin kombinasi dengan vitamin E atau injeksi xylocaine. Efek samping yang major dilaporkan jarang terjadi namun dapat bersifat fatal sehingga beberapa negara membatasi penggunaan quinin. ${ }^{25}$ Meskipun memiliki potensi efektif, penggunaan quinin sulfat untuk terapi kram otot harus dihindari selain karena efek sampingnya juga karena belum adanya evidence yang cukup untuk penggunaan yang spesifik untuk kram pada ALS. Quinin sulfat dapat dipertimbangkan untuk diberikan dalam kondisi kram sangat melumpuhkan, penggunaan levetirasetam tidak memberikan efek yang adekuat dan adanya pemantauan efek samping yang ketat. 19,29,63 $^{2}$

Sama seperti terapi untuk kram otot, sampai saat ini belum terdapat studi terkontrol yang dilakukan untuk melihat efikasi terapi spastisitas pada ALS. Terapi hanya berdasar pada benefit obat pada penyakit lain yang berhubungan dengan spastisitas atau pada studi yang tersedia, namun dengan desain open label yang menggunakan baklofen (PO dan IT), tizanidin, benzodiazepine, toksin botulinum, dantrolen dan levetiracetam. ${ }^{64,65}$ Namun, tidak ada satupun studi yang secara spesifik membahas tentang ALS tetapi lebih pada penyakit lain yang berhubungan dengan spastisitas yaitu multiple sclerosis dan cerebral palsy. Kebanyakan klinisi dari Itali 
menggunakan baclofen yang diikuti dengan tizanidin, benzodiazepin dan dantrolen, sedangkan pada sebuah survei yang dilakukan di Eropa, dilaporkan bahwa carbamazepin paling banyak digunakan. ${ }^{51}$

Pemberian baclofen IT dapat menjadi pertimbangan untuk diberikan jika baklofen oral tidak memberikan efek yang adekuat. Pada sebuah case series yang dilakukan oleh McClelland, sebanyak 8 pasien ALS dengan spastisitas severe dan nyeri diterapi dengan baclofen IT. Setelah pemberian baklofen IT, diketahui terjadi penurunan nyeri dengan rata-rata $54 \%$. Sebanyak enam pasien $(75 \%)$ mengalami penurunan skala nyeri, tiga di antaranya menggunakan analgesik. ${ }^{51,65}$

Guideline AAN dan EFNS memberikan rekomendasi standar penggunaan analgesik untuk nyeri muskuloskeletal dan sendi dapat mengikuti WHO pain ladder, hal ini karena belum adanya protokol spesifik nyeri untuk ALS sehingga dibutuhkan penelitian lebih lanjut dalam hal ini. ${ }^{7,20,21}$

\section{Simpulan}

Manajemen nyeri yang tepat pada ALS harus melibatkan pendekatan multidisiplin, karena pasien dapat mengalami nyeri akibat berbagai gambaran klinis yang berbedabeda, yaitu kram otot, spastisitas dan nyeri muskuloskeletal. Meskipun nyeri merupakan gejala yang penting pada palliative care, namun systematic studies terkait terapi nyeri pada ALS belum banyak dilakukan, sehingga clinical practice masih bergantung pada pengalaman dan preferensi pribadi klinisi dan bukan pada pendekatan yang sistematis. Oleh karena itu, dibutuhkan penelitian lebih lanjut terkait efikasi terapi nyeri pada ALS. Berdasarkan hasil penelusuran pada guideline dan evidence yang ada, didapatkan bahwa rekomendasi lini pertama untuk nyeri akibat kram otot dapat digunakan levetirasetam, sedangkan baklofen merupakan lini pertama untuk nyeri akibat spastisitas, dan lini pertama untuk nyeri sendi dan muskuloskeletal adalah asetaminofen atau NSAID.

\section{Pendanaan}

Penelitian ini tidak didanai dari sumber hibah apa pun.

\section{Konflik Kepentingan}

Seluruh penulis menyatakan tidak terdapat potensi konflik kepentingan dengan penelitian, kepenulisan (authorship), dan atau publikasi artikel ini.

\section{Daftar Pustaka}

1. Brettschneider J, Kurent J, Ludolph A. Drug therapy for pain in amyotrophic lateral sclerosis or motor neuron disease. Cochrane Database Syst Rev. 2013;(6): 1465-858. doi: 10.1002/14651858.CD00 5226.pub3

2. Zarei S, Carr K, Reiley L, Diaz K, Guerra $\mathrm{O}$, Altamirano PF, et al. A comprehensive review of amyotrophic lateral sclerosis. Surg Neurol Int. 2015;6(1):171-94. doi: 10.4103/2152-7806.169561

3. Delpont B, Beauvais K, Jacquin-Piques A, Alavoine V, Rault P, Blanc-Labarre C, et al. Clinical features of pain in amyotrophic lateral sclerosis: A clinical challenge. Rev Neurol (Paris). 2019;175(1-2):11-5. doi: 10.1002/14651858.CD005226.pub3

4. Yunusova Y, Plowman EK, Green JR, Barnett C, Bede P. Clinical measures of bulbar dysfunction in ALS. Front Neurol. 2019;10:106. doi: 10.3389/fneur. 2019.00106

5. Pizzimenti A, Aragona M, Onesti E, Inghilleri M. Depression, pain and quality of life in patients with amyotrophic lateral sclerosis: A cross-sectional study. Funct Neurol. 2013;28(2):115-9. doi: 10.11138 
/FNeur/2013.28.2.115

6. Paganoni S, Karam C, Joyce N, Carter GT, Hospital R, Hospital MG, et al. Comprehensive rehabilitative care across the spectrum of amyotrophic lateral sclerosis. NeuroRehabilitation. 2015;37 (1):53-68. doi: 10.3233/NRE-1512 40

7. Chiò A, Mora G, Lauria G. Pain in amyotrophic lateral sclerosis. Lancet Neurol. 2017;16(2):144-57. doi: 10.1016/ S1474-4422(16)30358-1

8. Oskarsson B, Gendron TF, Staff NP. Amyotrophic lateral sclerosis: An update for 2018. Mayo Clin Proc. 2018;93(11): 1617-28. doi: 10.1016/j.mayocp.2018.04 .007

9. Hanisch F, Skudlarek A, Berndt J, Kornhuber ME. Characteristics of pain in amyotrophic lateral sclerosis. Brain Behav. 2015;5(3):8-19. doi: 10.1002/brb 3.296

10. Yam MF, Loh YC, Tan CS, Adam SK, Manan NA, Basir R. General pathways of pain sensation and the major neurotransmitters involved in pain regulation. Int J Mol Sci. 2018;19(8): 2164. doi: 10.3390/ijms19082164

11. Rivera I, Ajroud-Driss S, Casey P, Heller S, Allen J, Siddique T, et al. Prevalence and characteristics of pain in early and late stages of ALS. Amyotroph Lateral Scler Front Degener. 2013;14(5-6):36972. doi: $10.3109 / 21678421.2012 .751614$

12. Stephens HE, Lehman E, Raheja D, Yang C, Walsh S, Mcarthur DB, et al. Pain in amyotrophic lateral sclerosis: Patient and physician perspectives and practices. Amyotroph Lateral Scler Front Degener. 2016;17(1-2):21-9. doi: 10.310 9/21678421.2015.1074701

13. Åkerblom Y, Jakobsson Larsson B, Zetterberg L, Åsenlöf P. The multiple faces of pain in motor neuron disease: A qualitative study to inform pain assessment and pain management. Disabil Rehabil.
2020;42(15):2123-32. doi: 10.1080/09638 288.2018.1555615

14. Wallace VCJ, Ellis CM, Burman R, Knights C, Shaw CE, Al-Chalabi A. The evaluation of pain in amyotrophic lateral sclerosis: A case controlled observational study. Amyotroph Lateral Scler Front Degener. 2014;15(7-8):520-7. doi: 10.31 09/21678421.2014.951944

15. Chen JH, Wu SC, Chen $\mathrm{HJ}$, Kao $\mathrm{CH}$, Tseng $\mathrm{CH}$, Tsai $\mathrm{CH}$. Risk of developing pressure sore in amyotrophic lateral sclerosis patients - a nationwide cohort study. J Eur Acad Dermatology Venereol. 2018;32(9):1589-96. doi: 10.1111/jdv.14 911

16. Oskarsson B, Moore D, Mozaffar T, Ravits J, Wiedau-Pazos M, Parziale N, et al. Mexiletine for muscle cramps in ALS: A randomized double blind crossover trial. Mayo Found Med Educ Res. 2018; 58(1):42-8. doi: 10.1002/mus. 26117

17. Caress JB, Ciarlone SL, Sullivan EA, Griffin, Leah P, Cartwright MS. The natural history of muscle cramps in amyotrophic lateral sclerosis. Muscle Nerve. 2016;53(4):513-7. doi: 10.1002/m us. 248920

18. Baldinger R, Katzberg HD, Weber M. Treatment for cramps in amyotrophic lateral sclerosis/motor neuron disease. Cochrane Database Syst Rev. 2012;4: CD004157. doi: 10.1002/14651858.cd00 4157.pub2

19. Soriani MH, Desnuelle C. Care management in amyotrophic lateral sclerosis. Rev Neurol. 2017;173(5):28899. doi: 10.1016/j.neurol.2017.03.031

20. Handy CR, Krudy C, Boulis N, Federici T. Pain in amyotrophic lateral sclerosis: A Neglected aspect of disease. Neurol Res Int. 2011;2011:403808. doi: 10.115 5/2011/403808

21. Oliver D. Palliative care in amyotrophic lateral sclerosis: From diagnosis to 
bereavement. In: Oliver D, Borasio GD, Johnston W, editors. Palliative care in amyotrophic lateral sclerosis. $4^{\text {th }}$ ed. United Kingdom: Oxford University Press; 2011.

22. Bromberg MB, Bromberg DB. Navigating life with amyotrophic lateral sclerosis. United Kingdom: Oxford University Press; 2017.

23. Andersen PM, Abrahams S, Borasio GD, de Carvalho M, Chio A, Van Damme P, et al. EFNS guidelines on the clinical management of amyotrophic lateral sclerosis (MALS) - revised report of an EFNS task force. Eur J Neurol. 2012;19 (3):360-75. doi: 10.1111/j.1468-1331.20 $11.03501 . \mathrm{x}$

24. Katzung BG, Trevor AJ. Skeletal muscle relaxants. In: Kruidering-Hall M, Campbell L, editors. Basic \& clinical pharmacology. $13^{\text {th }}$ ed. New York: Mc Graw Hill; 2015.

25. Amrix (Cyclobenzaprine Hydrochloride) Capsule [brosur]. USA: Teva Pharmaceuticals USA, Inc.; 2013 [diunduh 25 Februari 2020]. Tersedia dari: https:// www.accessdata.fda.gov/drugsatfda_doc s/label/ 2013/021777s012lbl.pdf

26. Metaxalone [brosur]. Bristol: King Pharmaceuticals, Inc.; 2018 [diunduh 25 Februari 2020]. Tersedia dari: https:// www.accessdata.fda.gov/drugsatfda_doc s/label/2018/013217s057lbl.pdf

27. Fudin J, Raouf M. Practical pain management. A review of skeletal mucle relaxant agent management. 2016 [diunduh 25 Februari 2020]. Tersedia dari: https: //www.practicalpainmanagement.com/tr eatments/pharmacological/non-opioids/ review-skeletal-muscle-relaxants-pain-m anagement

28. Hogan DB. Quinine: Not a safe drug for treating nocturnal leg cramps. Can Med Assoc J. 2015;187(4):248-53. doi: 10.1503/cmaj.150044

29. El Tawil S, T AM, Valli H, Lunn M, El
Tawil T, Wber M. Quinine for muscle cramps (review)-Summary of findings for the main comparison. Cochrane Database Syst Rev. 2015;4(12): CD0050 44. doi: 10.1002/14651858.CD005044pub3

30. Ashley C, Aileen C, editors. Quinine. In: The renal drug handbook. $4^{\text {th }}$ ed. United Kingdom: Radcliffe Publishing Ltd; 2014. doi: 10.1002/14651858.CD005044.pub3.

31. Wiffen PJ, Derry S, Moore RA, Lunn MPT. Levetiracetam for neuropathic pain in adults. Cochrane Database Syst Rev. 2014;2014(7):CD010943. doi: 0.1002/14 651858.CD010943.pub2

32. Bedlack RS, Pastula DM, Hawes J, Heydt D. Open-label pilot trial of levetiracetam for cramps and spasticity in patients with motor neuron disease. Amyotroph Lateral Scler. 2009;10(4):210-5. doi: 10.1080/17 482960802430773

33. U.S. Food and Drug Administration. Levetiracetam (Keppra) [brosur]. USA: United Collection Bureau; 2017 [diunduh 25 Februari 2020]. Tersedia dari: https:// www.accessdata.fda.gov/drugsatfda_doc s/label/2017/021035s099,021505s0381bl. pdf

34. Lee M, Silverman SM, Hansen H, Patel VB, Manchikanti L. A comprehensive review of opioid-induced hyperalgesia. Pain Physician. 2011;14(2):145-61.

35. Gabapentin (Neurontin) [brosur]. New York: Park-Davis; 2017 [diunduh 25 Februari 2020]. Tersedia dari: https:// www.accessdata.fda.gov/drugsatfda_doc s/label/2017/020235s064_020882s047_0 21129s046lbl.pdf

36. Kalra S, Cashman NR, Caramanos Z, Genge A, Arnold DL. Gabapentin therapy for amyotrophic lateral sclerosis: Lack of improvement in neuronal integrity shown by MR spectroscopy. Am J Neuroradiol. 2003;24(3):476-80.

37. Mexitil (Mexiletine Hydrochloride) [brosur]. Germany: Boehringer Ingelheim; 
2008 [diunduh 25 Februari 2020]. Tersedia dari: https://www.accessdata.fda.gov/dru gsatfda_docs/appletter/2004/18873slr01 81tr.pdf

38. Caroline A, Aileen D. Mexiletine. In: The renal drug handbook. $4^{\text {th }}$ ed. CRC Press; 2014.

39. Mylan. Baclofen Injection (Intrathecal) [brosur]. USA: Mylan Pharmaceuticals; 2017 [diunduh 25 Februari 2020]. Tersedia dari: https://www.accessdata.fda .gov/drugsatfda_docs/label/2018/209592 Orig1s0001bl.pdf

40. Rego S, Amorim I, Condeca B, Faria F. Efficacy of a second "drug holiday" in the treatment of intratechal baclofen tolerance - a case study. 2018;61:e359. doi: 10.1016/j.rehab.2018.05.838

41. McClelland S, Bethoux FA, Boulis NM, Sutliff MH, Stough DK, Schwetz KM, et al. Intrathecal baclofen for spasticityrelated pain in amyotrophic lateral sclerosis: Efficacy and factors associated with pain relief. Muscle and Nerve. 2008; 37(3):396-8. doi: 10.1002/mus.20900

42. Bethoux F, Boulis N, McClelland S, Willis MA, Hussain M, Machado A, et al. Use of intrathecal baclofen for treatment of severe spasticity in selected patients with motor neuron disease. Neurorehabil Neural Repair. 2013;27(9):828-33. doi: 10.1177/1545968313496325

43. Therapeutics A. Tizanidine (Zanaflex) tablet [brosur]. New York: Acorda Therapeutics, Inc.; 2013 [diunduh 25 Februari 2020]. Tersedia dari: https://www. accessdata.fda.gov/drugsatfda_docs/lab el/2013/021447s011_020397s026lbl.pdf

44. Mörkl S, Bengesser S, Schöggl H, Bayer D, Kapfhammer H. Tizanidine withdrawal symptoms in stress cardiomyopathy [in German]. Fortschr Neurol Psychiatr. 2015; 83(3):170-3. doi: 10.1055/s-0034-13991 67

45. Verma V, Singh N, Jaggi AS. Pregabalin in
Neuropathic pain: Evidences and possible mechanisms. Curr Neuropharmacol. 2014; 12(1):44-56. doi: 10.2174/1570159X120 1140117162802

46. Attal N, Cruccu G, Baron R, Haanpää M, Hansson P, Jensen TS, et al. EFNS guidelines on the pharmacological treatment of neuropathic pain: 2010 revision. Eur J Neurol. 2010;17(9):1113-23. doi: 10.1111/ j.1468-1331.2010.0 2999.x

47. Lyrica (Pregabalin) [brosur]. USA: Pfizer Inc.; 2012 [diunduh 25 Februari 2020]. Tersedia dari: https://www.accessdata. fda.gov/drugsatfda_docs/label/2018/021 446s035,022488s0131bl

48. Valium (Diazepam) [brosur]. San Fransisco: Roche Laboratories, Inc..; 2016 [diunduh 25 Februari 2020]. Tersedia dari: https://www.accessdata.fda.gov/dru gsatfda_docs/label/2016/013263s094lbl. pdf

49. Dantrium Capsules (Dantrolene sodium) [brosur]. Germany: JHP Pharmaceuticals; 2011 [diunduh 25 Februari 2020] Tersedia dari: https://www.accessdata.fda.gov/dru gsatfda_docs/label/2012/017443s043s04 $6 \mathrm{~s} 048 \mathrm{~s} 0491 \mathrm{bl}$

50. Pharmaceuticals C. Rilutek (Riluzole) [brosur]. USA: Covis Pharmaceuticals, Inc; 2016 [diunduh 25 Februari 2020]. Tersedia dari: https://www.accessdata.fd a.gov/drugsatfda_docs/label/2016/02059 9s017lbl.pdf

51. Dorst J, Ludolph AC, Huebers A. Diseasemodifying and symptomatic treatment of amyotrophic lateral sclerosis. Ther Adv Neurol Disord. 2017;11(6):1756285617 734734. doi: 10.1177/1756285617734734

52. Simpson DM, Hallett M, Ashman EJ, Comella CL, Green MW, Gronseth GS, et al. Practice guideline update summary: Botulinum neurotoxin for the treatment of blepharospasm, cervical dystonia, adult spasticity, and headache: Report of the Guideline Development Subcommittee 
of the American Academy of Neurology. Neurology. 2016;86(19):1818-26. doi: 10. 1212/WNL.0000000000002560

53. Marvulli R, Megna M, Citraro A, Vacca E, Napolitano M, Gallo G, et al. Botulinum toxin type a and physiotherapy in spasticity of the lower limbs due to amyotrophic lateral sclerosis. Toxins. 2019;11(7):381. doi: 10.3390/toxins 11070381

54. Vázquez-Costa JF, Máñez I, Alabajos A, Salazar MG, Roda C, Sevilla T. Safety and efficacy of botulinum toxin A for the treatment of spasticity in amyotrophic lateral sclerosis: results of a pilot study. J Neurol. 2016;263(10):1954-60. doi: 10. 1007/s00415-016-8223-Z

55. Mauskop A. Assessment: Symptomatic treatment for muscle cramps (an evidencebased review): Report of the therapeutics and technology assessment subcommittee of the american academy of neurology. Neurology. 2010;75(15):1397-9. doi: 10. 1212/WNL.0b013e3181f003be

56. De Carvalho M, Pinto S, Costa J, Evangelista T, Ohana B, Pinto A. A randomized, placebo-controlled trial of memantine for functional disability in amyotrophic lateral sclerosis. Amyotroph Lateral Scler. 2010;11(5):456-60. doi: 10. 3109/17482968.2010.498521

57. Weiss MD, Macklin EA, Simmons Z, Knox AS, Greenblatt DJ, Atassi N, et al. A randomized trial of mexiletine in ALS. Neurology. 2016;86(16):1474-81. doi: 10. 1212/WNL.0000000000002507

58. Valadi N. Evaluation and management of amyotrophic lateral sclerosis. Prim Care. 2015;42(2):177-87. doi: 10.1016/j.pop.2 015.01 .009
59. Nair KPS, Marsden J. The management of spasticity in adults. Br Med J. 2014;349: g4737. doi: 10.1136/bmj.g4737

60. Ferrari A, Manca M, Tugnoli V, Pini LA. Pharmacological differences and clinical implications of various botulinum toxin preparations: A critical appraisal. Funct Neurol. 2018;33(1):7-18. doi: 10.11138/ FNeur/2018.33.1.007

61. Lebeda FJ, Cer RZ, Stephens RM, Mudunuri U. Temporal characteristics of botulinum neurotoxin therapy. Expert Rev Neurother. 2010;10(1):93-103. doi: 10.1586/ern.09.134

62. Denenberg R, Curtiss CP. CE: Appropriate use of opioids in managing chronic pain. Am J Nurs. 2016;116(7):26-38. doi: 10.1 097/01.NAJ.0000484931.50778.6f

63. Katzberg HD, Khan AH, So YT. Assessment: Symptomatic treatment for muscle cramps (an evidence-based review): Report of the therapeutics and technology assessment subcommittee of the American academy of neurology. Neurology. 2010;74(8):691-6. doi: 10.12 12/WNL.0b013e3181d0ccca

64. Louisa Ng, Khan F, Young CA, Galea M. Symptomatic treatments for amyotrophic lateral sclerosis/motor neuron disease. Cochrane Database Syst Rev. 2017;(1): CD011776. doi: 10.1002/14651858.CD0 11776.pub2

65. Jackson CE, McVey AL, Rudnicki S, Dimachkie MM, Barohn RJ. Symptom management and end-of-life care in amyothropic lateral sclerosis. Neurol Clin. 2015;33(4):889-908. doi: 10.1016/j.ncl.2 015.07 .010 